\title{
Gaze, Face, and Theatricality: Facing the Faceless Man in a Burmese Parabaik-Painting of Royal Court Performances
}

\author{
Lorna Q. Israel \\ International Studies Department, Miriam College, Quezon City, Philippines \\ ORCID id 0000-0003-3747-6291, email: lisrael@mc.edu.ph
}

\begin{abstract}
Feminist scholars or artists see the world through the gender lens, which mastered the act of looking at men's pervasive presence. I encountered its limits while gazing at a figure in the $19^{\text {th }}$ century Burmese parabaik or folded paintings. In these paintings, which depict royal court performances, a figure emerges-a full-bodied man without a face. The painter granted him a faceless face and a gaze to follow. I embarked on a conversation with this faceless man by using the haptic eyes or that which faces the fleshly force of the painting. Who is this faceless man? Most importantly, why do my gendered eyes conclude that this figure is a man?
\end{abstract}

Keywords: Burmese folded paintings, face, gaze, parabaik painting, theatricality

\section{Introduction: Picturing Pictures}

A picture that accompanies an author's text is liable to become a casualty of our casual glance. We don't usually 'read' it as much as the writer's words. Similarly, the writer's words practically erase the picture for what we are actually 'reading' is a 'picture' of the writer's thoughts. This approach, according to Mitchell, will not do for the picture. He insists that we ask 'what a picture wants.'

What pictures want is not to be interpreted, decoded, worshipped, smashed, exposed, or demystified by their beholders, or to enthrall their beholders. What pictures want in the last instance, is simply to be asked what they want, with the understanding that the answer may well be, nothing at all (2005, my italics)."

Mitchell offers no method on how to ask what do pictures want, but reiterates its purpose: "to undermine the ready-made template for an interpretive mastery." He suggests treating as "an invitation to a conversational opening or an improvisation" with an 'indeterminate outcome' (Ibid.). Moreover, he wants to approach pictures as a 'complex individuals' with their own sense of existence or ontology.' This is because pictures can 'talk back' because of their "uncanny ability" to look back through the technique of omnivoyance. Thus, in our common way of talking, we can talk to a picture as if 'it was alive' (Ibid.).

Omnivoyance is also known as the Mona Lisa effect. It is an optical illusion that makes a person feels followed by the eyes in the painting (Hodne, 2012). Omnivoyance seems present even in something that does not have eyes. The sense of being followed trailed the young Lacan whose theory of the gaze has been "ridden with misinterpretations and burdened by some 40 years of fierce debates" (Carlsson, 2012). Lacan saw a 'hole' that

(C) AesthetixMS 2019. This Open Access article is published under a Creative Commons Attribution Non-Commercial 4.0 International License (http://creativecommons.org/licenses/by-nc/4.0/), which permits non-commercial re-use, distribution, and reproduction in any medium, provided the original work is properly cited. For citation use the DOI. For commercial re-use, please contact editor@chitrolekha.com 
is associated with a 'failure of the visual field' because it cannot be seen. What the eyes cannot see, however, the ears can. At bottom, the eyes and ears are holes on the face. These holes make a face recognizable even in the absence of the facial skin. We also associate the face with the head under the assumption that they belong together.

Deleuze and Guattari (1987) challenge the assumption that we have a face intrinsic to the body: "concrete faces cannot be assumed to come ready-made." It undergoes a 'process of facialization' where it 'takes shapes, given certain figures' because of the face's "fixed strata." The eyes, in particular, "are useless for they render back only the image of the known. As such, these shapes or features "are not inevitable characteristics of the facial landscape" (Ibid.). Parr (2005) underscores Deleuze and Guattari's intent: to strip a face of "any auratic or seductive power."

The idea of stripping face from itself is particular to Deleuze who discovered it from the portrait paintings of Francis Bacon: "Bacon pursues a very peculiar project as a portrait painter: to dismantle the face, to rediscover the head or make it emerge from beneath the face" (2003, italics original). The painter, Deleuze points out, "might paint with their eyes, but only as long as they touch with their eyes." Touching with one's eyes provides the "third eye" or the "haptic vision" that brings "new clarity" to the pictorial art (Ibid). With a haptic vision, the picture no longer simply addresses the eyes of the spectators, but unites their eyes with their mind as they "encounter the fleshly force of the painting" that is manifested in the use of color (Parr, Ibid.).

\section{Spectatorship and Theatricality}

A picture can assume a theatrical position because it can be 'staged.' For Fried (1988) a picture or a painting that establishes a "relation with the beholder is theatrical" and therefore "ingratiating and mediocre." The "best paintings" are "anti-theatrical," which means the spectators have been considered "as if [they were absent" (italics original). Fried wants an "absorbed" spectator, and not one who is conscious of watching something. Such a spectator compromises the actors' performance as they now 'address the audience and seek their applause' (Ibid.).

Theatricality, the very idea that brings the spectator into the picture, is what Fried wishes to divest from the picture. Fischer-Lichte (1997) brings it back into her own version of theatricality. She points out that there is no point differentiating between theatre and reality "for in the theatre as well as in everyday life, we construct our own reality" (Ibid.). Depending on their universe of discourse, the spectators could attribute meanings to the elements they perceived. That is to say, "perception was interpretation" (Ibid.) FischerLichte no longer sees the theatre as simply a constructed reality, but a "model of the process of constructing reality" where the

"role of the spectator was no longer to recognize and understand, but instead, to create his/her own reality. As a consequence, theatre was not to be defined anymore through its representation but through the process of construction which it triggers (Ibid., my italics). 


\section{Staging the Faceless Man in the Parabaik Paintings}

The 'spatial conception' of the theatre "invites the spectator's eye to wander between different points." In the course of their wandering eye, they are liable to miss something because they may simply choose what to see. What the spectator chooses to see is where theatricality-perception and interpretation-is staged. This is the showground where my eyes wandered through a $19^{\text {th }}$ century Burmese parabaik or folded book that depicts royal entertainments.

In the $19^{\text {th }}$ century, specifically the era of the Konbaung Dynasty, these important ceremonies include the "theatricals of marionette show, dances, music, and plays" (Singer, 1995). The parabaik or folding book captures these 'royal theatricals.' One such folding book has found its way to the digital section of the British Library courtesy of the Macfarlane couple who donated it. This parabaik is labelled 16761 by the British Library, and contains 16 court scenes that depict in watercolour painting, "elephant herding, royal procession, ceremonial ploughing, blessing ceremony, dramatical performances."

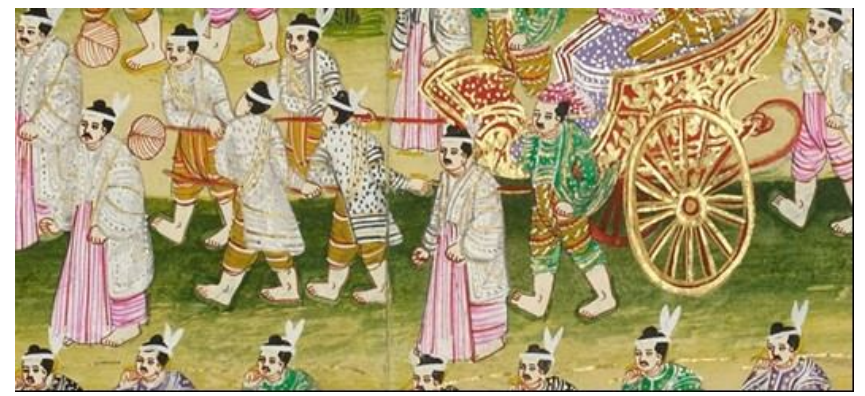

Figure 1: The faceless man (middle) in Folio 4

@) British Library Board, 16761, Folio 4, http://www.bl.uk/manuscripts/Viewer.aspx?ref=or_16761_fo04r

As my eyes wandered through the digital viewer manuscript of the British Library, one detail emerges - the shape of a head and a blank face. I initially thought that this was a singular, and therefore, isolated figure. But it is not. It is found on 13 out of the 16 folios of the parabaik. I wondered, what could this blank head/face mean? It does not even have a hole to signify eyes, mouth, nose or ears. Using the picture, gaze, spectatorship as my 'universe of discourse,' I sought to undertake a theatrical perception and interpretation of this faceless man to construct the reality therein. Following Mitchell's advice, I approached the parabaik as an 'improvised conversation with no definite outcome.'

\section{Into the crowd scene}

The crowded scenario of a royal court performance provides the perfect staging of the faceless man. He blends with the crowd and can easily be mistaken as one of the performers. In Folio 1 (elephant herding scene), he occupies a space at the bottom corner of the frame. Crouching on the ground, his left-hand gesticulating to a man in front of him, he acts as if whispering something important to a man in front of him. It draws the attention of other men whose sideway glances suggest their interest. They are listening to a 
conversation that deliberately excludes them. Nevertheless, the position of the faceless man suggests that he wants them included and excluded at the same time. The painter did not position the faceless man to whisper to the man in front of him. The earful attention of other men suggests they can hear the sound of the faceless man's whisper.

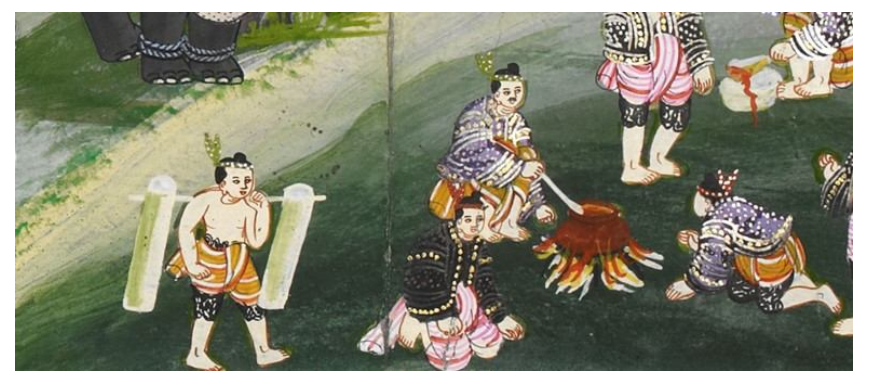

Figure 2: The faceless man appearing to announce something confidential in Folio 1

๔ British Library Board, 16761, Folio 1, http://www.bl.uk/manuscripts/Viewer.aspx?ref=or_16761_foo1r\#

\section{Duplicating Scenes}

Folio 4 (royal procession) repeats the blending-into-the crowd scheme for the faceless man. This time, however, the painter decided to duplicate him. In the center of the page, the faceless man becomes identical with another faceless figure. From a distance, they are indistinguishable, but the painter varied the other's one upper garment by making darker the dotted design, which is lighter in the upper garment of the other faceless man. By making their garments similar, these identical faceless men become hidden and revealed at the same time.

As in Folio 1, the faceless men seem to be saying something to the two men in front of them because their eyes look distracted. They are supposed to be pulling the royal carriage, but all seem preoccupied with looking into the beyond or something that cannot be found in the frame of the painting. All figures in the middle of the painting look straight at the outside the frame.

Folio 7 (ploughing ceremony) repeats the doubling of the faceless man. The painter has given them generous space of visibility. With clasped hands in a gesture of reverence, they are kneeling below the base of the royal canopy. One of them looks as if he is using his clasped hands to look at something he was not supposed to see. The other faceless man, however, seems to defy that injunction; he takes a lingering look at that which is forbidden (Figure 3).

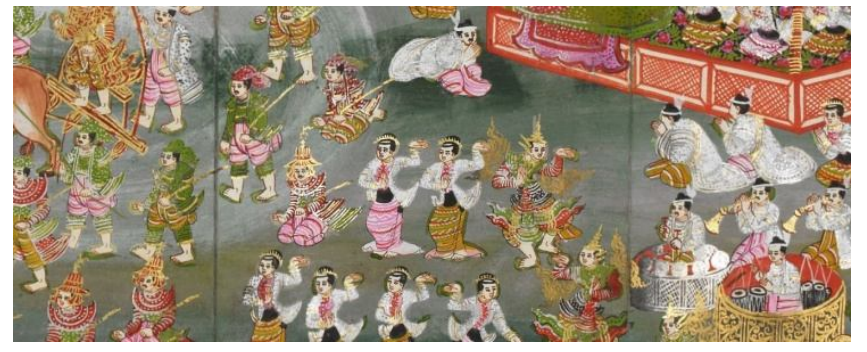

Figure 3: Identical Faceless Men in Folio 7 (upper right side) 


\section{The scene of becoming a group}

Folio 10 (another instance of elephant herding) has six faceless men, though two of them occupy a different spot in the picture. The bottom section of the page depicts four faceless men handling a dark grey elephant with a rope. Another dark grey elephant standing in front of these four faceless men cast them a casual look. With their faces turned toward this elephant, these faceless men seem to acknowledge the elephant's look. The same exchange of look between man and elephant is noticeable in the faceless man who is kneeling on a raised quadrangle where other male spectators are watching a dark grey elephant on performance. The elephant seems to look gently at the upturned face of these faceless men.

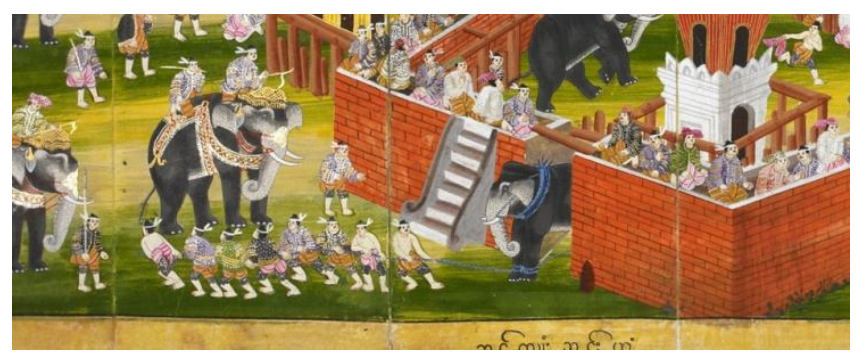

Figure 4: Group of Faceless Men in Folio 10

(c) British Library Board, 16761, Folio 10, http://www.bl.uk/manuscripts/Viewer.aspx?ref=or_16761_fo10r

Barely visible on the quadrangle is another faceless man who is kneeling down at some distant from the canopy where three female royal members are watching the elephant show. This particular faceless man is not looking at any one particular figure. His position suggests looking at something outside the frame of the painting. The three men and a flowering tree across him are blocking what this faceless man can see.

A group of four faceless men, dressed in military uniform, are in Folio 16 (consecration ceremony). Similarly attired in a soldier's uniform, they are at the bottom section of the page, and kneeling on the ground in a gesture of obeisance. Fronting the pavilion where the king and queen seat, the sideways angle of the head of the four faceless men suggests that they are talking to each other instead of paying attention to the royal figures across them. The painter seemed to have made this inattention reciprocal: the king and queen are conferring with each other. They do not look at their subjects or the royal entourage.

The grouping of the faceless man becomes frontal in Folio 35 (royal barge). The painter decided that a multiple of faceless men paddle the four boats escorting the royal barge. Except for their differently colored attire, the faceless men on the four boats appear the same. Each boat has a male skipper who seems to be giving the faceless men some instructions. The faceless men seem to be listening in full attention. Kneeling on the floor of the royal barge are four identical faceless men in front of three princesses. Owing to their stature, the princesses do not directly look at the upturned face of the four faceless men who are paying them a gesture of obeisance. The four faceless men look upward where the princesses are. 


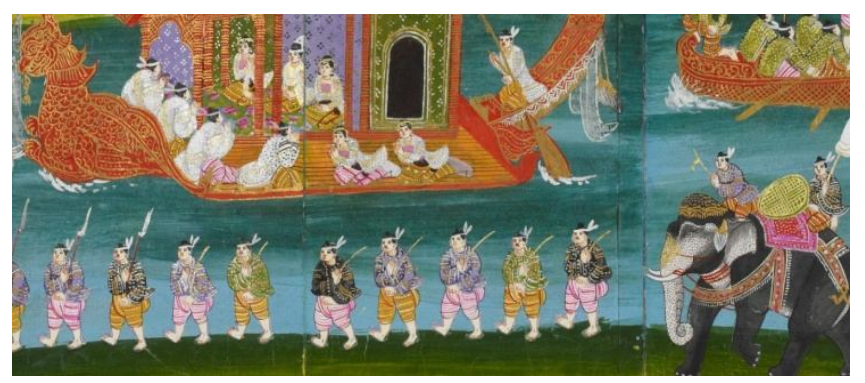

Figure 5 The four faceless men in front of the princesses

@ British Library Board, 16761, Folio 35, http://www.bl.uk/manuscripts/Viewer.aspx?ref=or_16761_fo35r

\section{The scene of becoming singular}

A lone faceless man in a military uniform atop a bedecked horse occupies the middle right corner of Folio 13. Fully and clearly visible, he is inspecting the result of the spear throwing competition that involves hitting the center of the circular target boards. From the smallest to the largest target boards, the throwers have proved their throwing prowess because all of them have scored bulls-eye. The most impressive thrower, however, would be the one that hit the smallest target board.

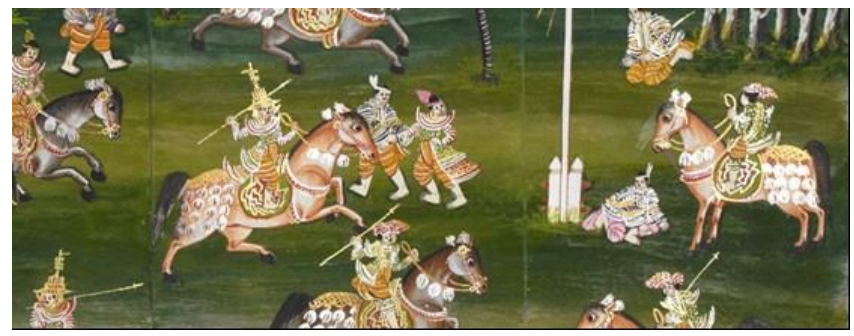

Figure 6: The Singular Faceless Man in Folio 13

๑) British Library Board, 16761, Folio 13, http://www.bl.uk/manuscripts/Viewer.aspx?ref=or_16761_fo13r

With a seemingly impassive stance, the faceless man does not look impressed. In fact, only a handful of men make the effort to look up and see the target boards. The three men who are looking at the faceless man seem to anticipate what he has to say. At the far end of the painting, everyone appears busy talking to each other. Here, at the left corner of the page, the royal members who are on their knees on the canopy appear interested on what the soldiers are reporting to them. Remarkably, the royal members will not see the dart boards. Aside from being far from the dart board, the men on horseback are blocking their view.

Not far from the royal canopy is a copy of the faceless man on the horse. He is kneeling on the ground in front of a man making an obeisance on the left corner of the frame. This scenario repeats the crowded atmosphere that barely makes visible the faceless man in Folio 1. This is repeated on the same spot of Folio 38 (elephant parade) where a faceless man pays obeisance to a woman who reciprocates his gesture. Both are kneeling on the ground near the royal canopy where a prince and four princesses sit. Noticeably, only 
the princesses are doing the sign of reverence as indicated by their clasped hands and halfbowing bodies.

\section{Staging the Gaze of the Faceless Man}

The faceless man, in one or in many, attracts the gaze of other figures in the parabaik. Having no eyes, the faceless man seems unaware of such a gaze. This scenario echoes Lacan's experience of looking at the can floating on the ocean, but it could not reciprocate his look. Following Deleuze and Guattari's claim that the eyes are useless because they can only recognize the known, the eyes in the parabaik are seeing the image of the unknown faceless man.

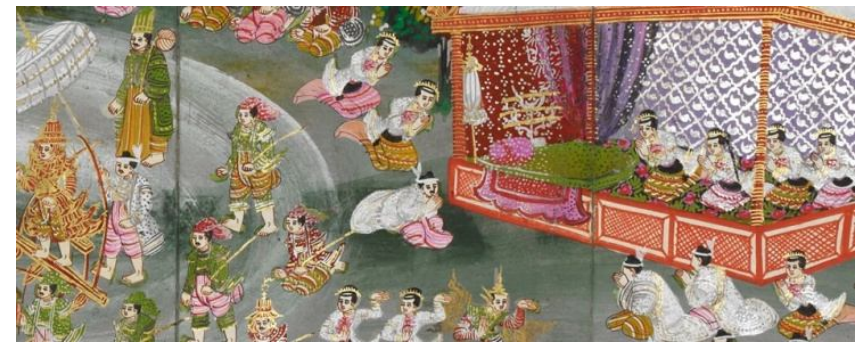

Figure 7: The intra-diegetic gaze of the faceless man in Folio 7 (bottom right side)

@ British Library Board, 16761, Folio 17 http://www.bl.uk/manuscripts/Viewer.aspx?ref=or_16761_fo07r

\section{The intra-diegetic gaze for the faceless man}

The intra-diegetic gaze addresses the characters or figures within the picture. This kind of gaze is present in Folio 1 where the eyes of the half-naked man indicates seeing the faceless man. The man on the ground conveys the same gaze at the faceless man while seemingly interested in the topic of conversation. Their distance from the talking men excluded them from the conversation. Their gaze, however, effectively renders their ears a voyeur. Their eyes tell them that the men are talking about something, but their distance prevents them from hearing it.

Folio 4 suggests the same action of the intra-diegetic gaze. Men in the middle of the picture and those at the bottom look at the two faceless men. Their voyeuristic ears suggest their attempt to listen to what the half-naked man in Folio 1 fails to hear. Folio 1 and 4, therefore, present two unknown objects of the intra-diegetic gaze: the faceless man himself and the topic of conversation where he participates. In Folio 7, the imagery of a faceless men bearing something to talk about has disappeared. The intra-diegetic gaze comes from a dancing soldier who looks at one of the faceless men and wondering if there's something wrong. Three male musicians behind this faceless man also register the same wondering look at this faceless man.

In Folio 13, the eyes of the soldier who stands across the faceless man atop a horse also suggest a wondering look. This soldier appears wanting to know if the faceless man can actually see the result of the spear throwing on the target boards. But the impassive and unimpressed stance of the faceless man does not offer him any clue. The faceless man is 
looking up, but his eyes seem to have landed on the side of the pole with no target boards. The faceless man is looking at something only he knows.

\section{The intra-diegetic gaze by the faceless man}

The faceless man enacts an intra-diegetic gaze addressed to the royal members. Of the four faceless men in Folio 19, one directly looks at a princess on a canopy. The princess, however, does not seem to look at him. Her eyes reciprocate the gaze of the man beside the faceless man who looks at her.

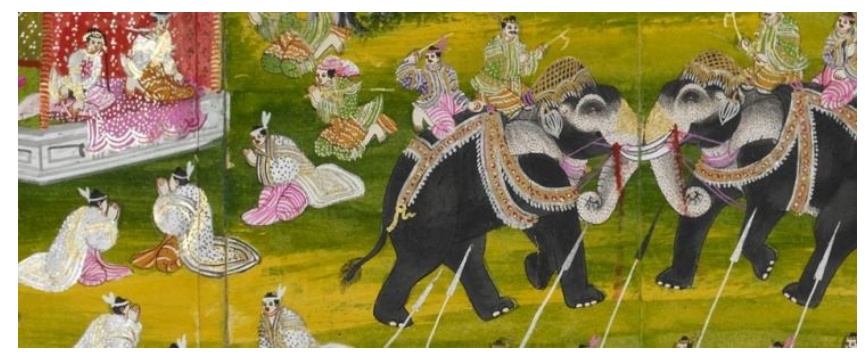

Figure 8: The faceless man's unreciprocated gaze in Folio 19

๑) British Library Board, 16761, Folio 19, http://www.bl.uk/manuscripts/Viewer.aspx?ref=or_16761_fo19r

The gaze of the faceless man in Folio 25 is also unreciprocated. The three male nonroyal figures on the canopy intra-diegetically gaze at each other as if confirming something between them. The rest of the figures in this folio look at these three men to finally say something, including the faceless man. Folio 28 repeats the unreciprocated look between the faceless man the princesses on the canopy in Folio 19. The princesses exchange looks with the other male figures, but not with the faceless men who are also within their eyesight.

It seems that the faceless man will not exchange looks with the royal members. In Folio 35, where they are up close and face to face with the princesses, the faceless men remain unseen by the royal members. In Folio 38, however, one of the women comprising the royal entourage seems to have descended from the royal canopy. Kneeling face to face with the faceless man, she looks at him. But the slightly angled face of the faceless man suggests that his eyes are on the queen and the princess who are communicating with men near the canopy through their eyes.

Of all the figures in the parabaik, it is the royal members who do not seem to see the faceless man. This could not be interpreted as an act of snobbery because they have exchanged looks with fully faced male figures within their field of vision. The faceless man has also been put in the same scenario, but with the non-royal male figures and one female. They see the faceless man, but the positioning of the head of the faceless man suggests overlooking or refusing to see those who can see him. The faceless man cannot and will not look at those who see him. He wishes to remain anonymous, which his facelessness cannot grant. The artist had ensured that his anonymity becomes his knowability. He is, thus, known as the anonymous and faceless man. 


\section{Conclusion: Painting one's face into anonymity}

The fact that all the faceless men in this parabaik resemble each other suggests that there is only one faceless man. The fact that his peers (or the non-royal figures) have actually looked at him suggests that he is quite known to them. The fact that he is unseen by the royal members all throughout further suggests that he is one of their unknown and therefore, faceless subjects. What better way to confirm one's anonymous and unknown status than by painting it on the same activity that will consign him to anonymity and facelessness anyway. The faceless man on the parabaik is none other than the painter himself. His facelessness becomes the focal face in the Burmese folded paintings. Despite this, he remains elusive, which makes him so obvious nevertheless. This brings me to the most obvious feature of this faceless figure; apparently, it is a man.

Figures recognizably male (with mustache) or female (with a tiara) surround this faceless figure. He is also depicted as doing 'men's work such as pulling the royal carriage). It led me to assume that it is a man. Indeed, it is my gendered eyes that give this faceless figure with a man's face. Clearly, it is just that-a faceless figure who wishes to stay that way. Thus, this faceless figure is asking me, "how do you know I am a man?" It has divested me of interpretive mastery.

\section{References}

Hodne, L. (2013). Omnivoyance and Omnipresence. Word and Vision According to Nicholas of Cusa and Jan van Eyck. IKON, 6, 237-246. doi: 10.1484/j.ikon.5.102952

Deleuze, G. (2003). Francis Bacon: The Logic of Sensation. Trans. Daniel W. Smith. London/New York: Continuum.

Deleuze, G., \& Guattari, F. (1987). A Thousand Plateaus: Capitalism and Schizophrenia. Trans. Brian Massumi. Minneapolis/London: Minnesota University Press.

Fischer-Lichte, E. (1997). The Show and the Gaze of Theatre: A European Perspective. Iowa: Iowa University Press.

Fried, M. (1988). Absorption and Theatricality: Painting and Beholder in the Age of Diderot. Chicago: University of Chicago Press.

Mitchell, W. F.T. (2005). What Do Pictures Want: The Lives and Loves of Images. Chicago/London:

University of Chicago Press.

Parr, A. ed. (2005). The Deleuze Dictionary. Edinburgh: Edinburgh University Press.

Singer, N.F. (1995). Burmese Dance and Theatre. Kuala Lampur/ New York: Oxford University Press.

Lorna Q. Israel currently teaches in the International Department of Miriam College where she used to handle courses on women in arts, and history of contemporary Asian art. She is the immediate past president of Kasibulan, a women's art group based in Manila, Philippines. 